\title{
Correction to: New editors-in-chief and 40th anniversary of RRR
}

\author{
Mikaela Backman' ${ }^{1}$ Thomas Brenner ${ }^{2}$ - Georg Hirte ${ }^{3}$ Iris Wanzenböck ${ }^{4}$
}

Accepted: 5 July 2021 / Published online: 22 July 2021

(C) The Author(s) 2021

\section{Correction to:}

\section{Rev Reg Res 2020}

https://doi.org/10.1007/s10037-020-00138-3

The article New editors-in-chief and 40th anniversary of RRR, written by Mikaela Backman, Thomas Brenner, Georg Hirte and Iris Wanzenböck, was originally published Online First without Open Access. After publication in volume 40, issue 1, page 1-2 the author decided to opt for Open Choice and to make the article an Open Access publication. Therefore, the copyright of the article has been changed to (CThe Author(s) 2020 and the article is forthwith distributed under the terms of the Creative Commons Attribution 4.0 International License, which permits use,

The online version of the original article can be found under https://doi.org/10.1007/s10037-02000138-3

Mikaela Backman

mikaela.backman@ju.se

Thomas Brenner

thomas.brenner@uni-marburg.de

$\triangle$ Georg Hirte

georg.hirte@tu-dresden.de

Iris Wanzenböck

i.wanzenbock@uu.nl

1 Jonköping International Business School, Jonköping, Sweden

2 Universität Marburg, Marburg, Germany

3 Technische Universität Dresden, Dresden, Germany

4 University of Utrecht, Utrecht, The Netherlands 
sharing, adaptation, distribution and reproduction in any medium or format, as long as you give appropriate credit to the original author(s) and the source, provide a link to the Creative Commons licence, and indicate if changes were made.

Funding Open Access funding enabled and organized by Projekt DEAL

Open Access This article is licensed under a Creative Commons Attribution 4.0 International License, which permits use, sharing, adaptation, distribution and reproduction in any medium or format, as long as you give appropriate credit to the original author(s) and the source, provide a link to the Creative Commons licence, and indicate if changes were made. The images or other third party material in this article are included in the article's Creative Commons licence, unless indicated otherwise in a credit line to the material. If material is not included in the article's Creative Commons licence and your intended use is not permitted by statutory regulation or exceeds the permitted use, you will need to obtain permission directly from the copyright holder. To view a copy of this licence, visit http://creativecommons.org/licenses/by/4. $0 /$. 